\section{Designing Water Institutions}

\section{Market Failures \\ and Institutional Response}

Marie Leigh Livingston
Successful water institutions require a delicate interplay between administrative and market control. The complex challenge for water professionals is to design institutions to deal with the physical peculiarities of water in a way that establishes sensible incentives and efficient use of resources.

The World Bank

Agriculture and Naiural Resources Department Agricultural Policies Division

December 1993 


\section{Summary findings}

To foster economic efficiency, says Livingston, right: to water resources must be both secure and flexible. Designing institutions to deal with the physical peculiarities of water in a way that establishes sensible incentives and efficient resource use is complicared.

Basically, establishing security in water rights requires protecting water users against intrusion by others. This is challenging, since water users are naturally interdependent. Security does not mean that one must be guaranteed an exact amount of water aii the time. Rather, it means knowing the probability of water availability and beirg certain about allocation procedures under changing circumstances.

Economic efficiency in warer allocation in response to short-term supply changes (such as droughts) requires that economically sensitive sectors take precedence over less sensitive or more adaptive sectors. This can be accomplished through markets or administratively (by government agencies or private water user groups). In a market scheme, rights must be differentiated according to the probability of receiving water in times of shortage. Those with high-value uses can then either acquire high-probability rights permanently or negotiate an option to be exercised only in drought years.

There is le:s agreement among experts ahout how to design institutions to provide flexible water allocation in response to long-run changes in demand. Certainly no one interested in economic efficien.y would suggest either a complete ban on transfers or completely unrestrained transters. The difficulty is to ensure that water transactions allow economic development and do not impose externalities on other water users.

Market mechanisms for water transfer can entail substantial transaction costs, which threaten to delay or stymie transfers altogether. Moreover, third-party and community etfects continue to cencern those involved in water transfers. Local citizens and of ficials raise issues about the distribution of economic activity rather than its aggregate level (economic efficiency). Perhaps these issues are negligible when the amcunt of water transferred is small in proportion to total supply. But when the transfer threatens a community's economic base, these concerns deserve more consideration.

Successful water institutions require a delicate interplay between administrative and market control. Institutions establish the basis for markets and can as ure competitive conditions. Water agencies will always be involved in allocation, given the economies of scale in centralized water management. The chalkenge for water professionals is to structure institurions so that they foster sound ecrnomic development.

This paper - a product of the Agricultural Policies Division, Agriculture and Natural Resources Department - is part of a larger efforr in the deparment to provide guidance on water resources management. Copits of the paper are available free from the World Bank, $1818 \mathrm{H}$ Streer NW, Washington, DC 20433. Please contact Cicely Spooner, room N8.03\%, extension 30464 (25 pages). December 199.3.

The Policy Research Working Paper Sertes dissemonates the fin ings of witk in frogress to encourage the cxi hange of ticas about development issues. An objective of the series is to get the findings out quickly, even if the presentations are loss than fully polished. The papers cary the names of the authors and should be used and cited accordingly. The findings. inte pretations, and conclusions are the authors' own and should not be attributed to the World Rank, its Executive Boart of Directors, or uny of us member countries. 


\section{DESIGNING WATER INSTITUTIONS: MARKET FAILURES AND INSTITUTIONAL RESPONSE}

by

Marie Leigh Livingston

Consultant, AGRAP

Provided as background to The World Bank Water Policy Papen, January 13, 1992. The author has benefitted from critical reviews by W. K. Easter, W. B. Lord, S. C. Nunn and R. K. Sampath. 


\title{
DESIGNING WATER INSTITUTIONS: \\ MARKET FAILURES AND INSTITUTIONAL RESPONSE
}

\section{INTRODUCTION}

\begin{abstract}
Efficient resource use is increasingly central to the economic: well being of individual regions and countries. Instituiional arrangements set the ground rules for resource use. Institutions are "ordered relationships among people which define their rights, exposure to rights of other, privileges and responsibilities (Schmid, 1972, p. 893). They determine who has the right to claim the benefits from resource use and who must bear costs (Bromley, 1982). Therefore, institutions establish the incentives, information and compulsions that guide behavior and determine economic outcomes.
\end{abstract}

Institutional arrangements establish the basis for market or administrative control over water. it best, institutions create order and relative certainty for water users which facilitate achievement of economic and social goals. At worst, they establish impediments to efficient resource use and significant resources must be expended by individuals to compensate for their obsolete or poor design (North, 1987). The structure of water institutions continues to be important because while significant investments have been made in water facilities, realizing the potential of these investments requires appropriate institutional arrangements to guide their use.

Institutions establish the interface between government and market control over water resources. Broadly speaking, government policies establish the "rules of the game" and simultaneously define the range over which markets and individual choice can operate. Markets cannot exist without some government control over water resources; in the absence of government there is no basis for binding contracts between individuals. Water resource management will always necessarily involve some mix of government and market control over the resource. 
The mix uf government and market control over water depends, of course, on a particular country and its cultural, political and economic history. These factors obviously also influence the prospects for institutional innovation. Any general statement about the mix of government and market control over water is bound to have its exceptions. Nevertheless, in general, one can say governments are usually more involved it macro lavel resource management, which may involve identifying priorities, mediating conflict and selective provision of services.

While inicro level resource management often relies on private organizations and markets, no smali share of water is micro managed directly by governments in many parts of the world. In any case, the ideal role of macro level government control over water is to structure institutions such that externalities are taken into account, thereby "enabling" individuals to manage their own resource use efficiently.

Poorly functioning resource instituticns tend to generate pressure for innovations in policy. It is common for institutional arrangements to lag behind evolving technology and social values. This phenomenon has been studied in general (North, 1987; Ruttan and Hayami, 1984) and in the context of water policy (Dunbar, 1977; Livingston and Ruttan, 1990; Runge, 1987). One important question becomes which institutional forms should be coraidsred in addressing, and potentially resolving, inefficient resur ze use.

Mass and Anderson (15.2., p.2) state that the fundamental purpose of water institutions "is to provide order and predictability so that wator users can realize their other goals related to income, popular control and social justice ..". Here, the focus is on economic efficiency, meaning the facilitation of economic development that can be sustained over the long term, without undue environmental or social disruption. In reality, pursuit of strict economic efficiency may be circumscribed by other considerations including political and equity goals. Nonetheless, understanding the impact of altennative institutional arrangements on economic efficiency is critical to informed decision making.

The peculiar characteristics of water resources pose special challenges for institutional design. Water resources are prone to market failures that must be addressed by institutions in order to yield efficient allocation and use. Also, water allocations must change in order to adapt to changing physical and economic circumstances. In order to facilitate sound economic development, water institutions must create security and flexibility (Ciriacywantrup, 1956). The first requirement concerns market failures; the second pertains to reallocation. 
The objective of this paper is to describe problems faced in designing the structure of water institutions and to discuss institutions that have been found to be particularly successful or unsuccessful in dealing with common market failures and for reallocating water in times of climatic and economic change. The following section discusses marjet failures endemic to water resources and potential institutional responses to them. subsequently, the topic of institutions for reallocating water within and between sectors ill be addressed.

\section{WATER RESOURCES AND MARKET FAILURE}

Economic theory suggests that under specific conditions, markets will yield accurate incentives and foster efficient resource use. These conditions are very restrictive, but may be met to greater or lesser degree in specific resource and goods markets. When particular conditions are not met, markets do not yield appropriate incentives and "fiil" to achieve efficient resource use (Randal1,1983). In the case of water resources, many assumptions are violated insofar as water is fugitive, lumpy and rife with externalities. Moreover, water use is often nonrival, entails substantial transactions costs and suffers from information deficiencies.

The physical nature of water alone violates a number of these conditions, and institutional and technical accommodation are necessary to render efficient markets (Livingston, 1985). Two central conditions necessary for a market system of resource allocation to function efficiently include: 1) the resource user must be certain of the quantity, quality, location and timing of resource availability, 2) the resource must be perfectly divisible and 3) resource use must not effect, or be effected by, utilization of the resu ace by another party. Certainly, in the absence of institutional control, these conditions are not met in the case of water resources. The applicability and significance of each is explained below.

The nature of the hydrologic cycle determines water supply. The distribution and form of that supply charges over space and time, which effectively changes the supply of water available for use at a specific site. Extreme within year variability in precipitation and streamflow tend to be the rule, rather than the exception in rator supply. This is esperially true in arid regions where water allocation: is more critical. Uncertainties as to the physical quantity of water available at particular times and locations impede efficient resource use by lessening the expected value of engaging in water related activities. 
The fugitive nature of water also creates physical uncertainty. Without institutions, the right to use water is gained solely through capture in a canal or reservoir. Under these conditions deferred use carries no guarantee of future availability. Institutions are necessary to establish the rules for diversion from streams for direct use and for storage for later use.

The fact that water is "lumpy" (i.e. is not perfectly divisible in terms of storage or transportation) also poses special problems for institutional design. Water supplies exist in discrete "chunks" and is naturally concentrated into site specific, common pools or streams. The implications are dramatic. First, very significant economies of scale exist in pumping and delivery. Where diversion is necessary, individual irrigators, for instance, are usually unable to transport small amounts of water in isolation, due to conveyance losses. Therefore, indivisibility means that water allocation and use must, by necessity, involve group decisions and actions. Therefore management becomes a problem for the group as a whole, rather than for specific individuals.

Second, Iumpiness also generates violation of perhaps the most important condition for efficient water use: independent production and consumption functions. Because water supplies are concentrated, withdrawal, consumption and return flows by one individual, in all likelihood, effects the quality, quantity and timing of supply for individuals downstream. Without lequate institutional arrangements, efficient utilization is inhibited because all costs imposed by water users are not necessarily born by the users themselves. That is, private costs and benefits diverge from social costs and benefits, which yields serious distortions in allocation.

\section{INSTITUTIONAL RESPONSE TO MARKET FAILURE: SECURITY}

Societies around the world necessarily (explicitly, implicitly, or by default) establish institutional arrangements that govern water use. Some systems utilize markets, with various degrees of imperfection and efficiency. Many other resource allocation systems lack market mechanisms all together. Whether market or administrative based, some regimes are more effective than others in addressing the characteristics of water and creating a system of secure water rights necessary for efficient resource use. A few illustrative examples are presented below. 
Security Through Proportionality, Priority and Absence of Damage

Muci of the world in need of rigorous water management experiences extreme variability in precipitation and streamflow throughout the year. In an analysis of 35 developing countries, Cestti (198\%) reports that nearly half of these countries experience to\% variability in rainfall. Typically, this physical uncertainty has been dealt with through a combination a technological and institutional accommodations, in order to produca relatively secure water rights.

The technical aspect of creating security involves developing storage facilities to capture water during periods of high streamflow (usually due to spring snow melt) and preserving it until times of lower streamflow and higher demand. This activity, in itself, greatly enhances the security of water availability.

The institutional approach to security may be based on proportionality or priority. In the case of proportionality, the insecurity inherent in variable water supplies is shared among water users of a given supply. Water rights are defined as a percent of the water available in any given year. For example, some localities in Australia use the concept of "capacity sharing" to reduce uncertainty (Ludley, 1991). Share holders in a dam project receive a certain percentage of dam capacity and streamflow. While the percentage is constant, the actual quantity of water received will vary from year to year. In tis way, the structure of water rights spreads the risk of variability equally among share holders.

An alternative approach to the security issue is represented by the concept of priority in time, as used in the Western U. S. Actually, the approach is two-fold. First, the doctrine of prior appropriation (in contrast to riparian water rights) addresses the market failure of uncertainty in supply. The appropriation doctrine simply stipulate that senior (prior) water rights are fulfilled before junior rights, which are acquired later in time. Thus, based on temporal priority, a water user can be relatively certain about the prospects for receiving water in a particular year. The more junior the right. the less likely that right is to be fulfilled.

Second, the joint problems of indivisibility and interdependce are addressed by the far-reaching doctrine of "absence of damage". This principle dictates that the appropriation of a new water right cannot in any way damage existing rights. In this way, existing water users can be secure in the knowledge that subsequent right holders cannot adversely effect the quality or quantity of streamflow available to them. Because many surface and subsurface water suppiies are physically connected, this principle has been extended to apply to conjunctive management of suriace and groundwater (Young, Daubert and Morel-seytoux, 1986). 
In the Western U.S., a water right must be continually used in order to be valid. Non-lse results in "abandonment" or "forfeiture". '.. is principle has a two pronged effect on security and therefore water allocation. Some economists argue that in order to protect the security of a water right, right holders use their maximum cntitlement, regardless of need. This incentive results in overuse of water resources. On the other hand, these loss doctrines are necessary in order to prevent "sleeper rights", which introduce uncertainty into the overall system.

Enforcement c: these doctrines requires both technology and institutions. The number of senio: rights expected to be fulfilled in a given year is determined by snowpack measurements and satellite monitoring of streamflows. Water commissioners are "rive: cops" who also monitor water withdrawals to ensure actucil use and compliance with priority. Violations of priority and absence of damage rules are institutionally enforced either administratively, or through a system of water courts. For example, in colorado, any right holder can bring litigation against anotrer user who violates these principles.

\section{Iicenses and security}

Some aspects of the Australian system of water allocation results in water rights that are significantly less secure than those discussed above. All water supplies are held by the state, and rights to use are acquired by obtaining a license, which are not prioritized. Rather than relying on strict legal principles, state officials have wide discretion in determining the conditions that apply to licenses (Delforce, Pigram, Musgrave and Anderson, 1990).

The security of a licenses is lessened by several factors. First, the license can be modified at any time, at the discretion of governmental agencies. Second, licenses are not granted in perpetuity; they expire periodicaliy. Finally, there ara a significant number of "sleeper licenses" on the books, meaning licenses that have been granted, but are not currently in use. These sleeper licenses are not lost through nonuse, and can be activated at any time, which introduces another element of uncertainty into the water allocation system.

The security of water rights in the western $U$. $S$. is compromised by sleeper "reserved" water rights. Reserved water rigits are those accruing to Indian or other Federal reservations of lana. These lands carry an implicit right to the water necessary to achieve the designated purpose of the land and carry a priority date equal to the reservation date. Unlike other water rights, reserved rights are not lost from non use. To date, 
reserved rights are largely unexercised and unquantified within this general concept, which creates great uncertainty. Under must scenarios, the iull and eventual use of these rights will likely supplant a significant fraction of existing water uses.

An all-knowing governmental body sould theoretically constrict a system of secure licenses, if they were able to anticipate all eventualities, and iespona iluromatically to changing circumstancas. On the other hand, if decentralized systems accoun: for external impacts, individual transactions tend ro produce better economic outcomes (Anderson, 19\%\%). However, ise pioblems of water management often invol e more than efficiency alone. public as well as private security may be at issue. Political, environmental and equity goals may also be involved. As a result, markets, as well as centralized bureaucracies are inadequate in meeting these challenges singlehandedly. A complicated mix of the two is typically called for.

\section{Lack of Security and The Rule of Intrusion}

Thailand exemplifies the case where markat failures are totally ignored, with devastating impacts on water security and efficient use. The old say "not to decide, is to decide", certainly applies to Thailand. There are no formalized institutional rules for water allocation (Johnson, Patamatamkul, onchan and Tan-KimYong, 1990), and in the absence of formal rules, the informal rule of right by intrusion and capture applies (Randall, 1983).

In this case, a water "right" is obtained simply by diverting water from the stream. However, this right is, in no sense, secure. As the demand for watrr grows, additional diversions from the stream are not constrained from damaging existing use. If an entity wishes to irsrease its water security, the typical approach is to simply increased efforts devoted to water capture, which may negatively impact downstream users. The result is extreme overall resource insecurity. Significant pressure exists to develop institutional arrangements capable of dealing with the inevitable chaos and conflict that results.

Informal, customary rights to water can be somewhat secure and yet susceptible to intrusion. In both Indla and Indonesia, water rights are gained prescriptively, that is customary rights are recognized based on historical use of communal systems (Berkoff, 1991). The security of such rights is usually partially protected. In general, such water users achieve considerable protection from intrusion from outside the basin in question. Typically, they would not be afforded the same guarantees against additional users within the basin itselî. 
In the Philippines, prescriptive water law has been entirely repealed (Cruz, Cornista and Dayan, 1987). Until recently, Philippine wate = law was based on spanish water law that recognized acquisitive prescrintion in the use of public waters. However, the current water code expressly reverses this principle. Obviousiy, historical use based on prescr. iption has become extremely insecure.

Establishing security in water use is recessary in order to establish efficient wat $r$ use, but it is not sufficient. Security, and the order that results, is a prereyuisite to efficiency. However water rights must also $k$ ? flexible. The next section outines the flexibility issue in general and its importance to efficiency.

\section{THE IMPORTANCE OF FUEXIBILITY IN WATER ALLOCATION}

In order to facilitate economic well being and growth, institutiorai arrengements must accommodate the need for reallocating water over time, in response to legitimate and accuratelv represented social economic need. Institutions are critical is determining whether water transfers proceed smoothly and in response to bone fide efficiency concerns, whether they incorporate inappropriate or inaccurate considerations, or disallow reallocation al together.

Reallocation of water within and between sectors is supported on grounds of economi- efficiency, wherein water is transferred to its highest valued use (Howe, Schurmeier and Douglas, 1986; Hartman and Seastone, 1970). Fluctuation in water demand and water supply can create substantial discrepancies between the existing allocation of water and the efficient allocation wherein net economic returns are maximized (Vaux, 1986).

Certainly, the developing world faces substantial changes in future water supply and demand conditions, that call for water reallocation as part and parcel of an overall solution. Certainly, future water supplies are subject to change, given "regular" drought occurrences as well as atypical changes due to desertification, climate change and the like. Decreases in water quality are increasingly significant to water supply problems.

Demand condi ons are bound to change as well. Population growth alone indicates an increase in water scarcity. Sestti (1989) defines three categories of scarcity based on the number of people competing for ons flow unit of water (one million cubic meter per year). The categories are 1)adaptation problems at 500 people/mcm/yr, 2) absolute scarcity at 1000 people/mom/yr and 3) water barrier at 2000 people/mcm/yr. Assuming stationary 
population, countries in catesory, 1 include China, Cyprus, El Salvadur, India, Irag, Mexico, sri Lanka, Sudan, Thdiland, and Turkey. Category 2 includes Ghana, Iran, Madagascar, Mauritania, Peru, S. Africa, and Togo. Category 3 includes Algeria Cape Verde, Egypt, Israel Jordar, Morocco, Oman Saldi Arabia, Ayria, Tunisia and Yemen.

Increases in irrigated acreage in the developing world will ilso place additional demands on iocal wacer supplies. Growth rates in irrigated acreage averagad at about thirty percent during the 1970's (Cestti, 1989). In some areas, urbanization will necessitate reallocation. Mexico $c . ' y$, Amman Jordan and Beijing are examples of cities facing wate shortages in the face of growth. Industrialization is also $z$ key factor in some parts of the world, especially the newly developed econonies of Asia.Continuation of this trend has very substantial implications for the reallocation of water coographically as well as sectorally.

When water is locked in historical uses, rather than reallocited as economic conditions change, efficieilcy losses can be substantial. For example, in terms of overall shottage, Fallon and Dixon (1989) conclude that an estimated water shortage of 3.5 billion cubic meters in Beijing in the year 2000 could be alleviated through a combination of technical and policy options including reallocation within and among sect irs.

Water economists in the developed world have increasingly reliable estimates of the savings to be realized through water trades and transfers. Vaux (1986) focuses specifically on poten ial trades from agricultural to urban use in Caifornia. He estimates that reallocation of ten percent of agricultural water to cities could yield benefits of 169 million dollars by the year 2000 and reduce overall water use.

Sirilarly, Kelso, Martin and Mack (1973), provide extensive economic analysis of the central Arizona project. Their study also indicates that the structural project is uneconomical. That is, growing water demands could be met at lower cost through reallocation of existing supplies. Gisser and Johnson (1983) and Burness and Quirk( ) see the same sort of inefficiency elsewhere in the Western U.S.

Given that one accepts the fact that reallocation of water over space, uses anc time is necessary and desirable in order to maximize development benefits, the question becomes what vehicle should be used to achieve such changes. The answer lies in some mix of administrative and market control.

The mix of market and administrative mechanisms chosen and usea will necessarily vary between countries. The efficiency implications of particular combinations will vary somewhat depending on local circumstances. In general terms the degree to 
which e:ther approach dominates depends on the following factors. First a courtry's experience with command and control vs. a market based economy will influence, to substantial degree the type of approach selected. A country's stage in development and historical background will necessarily impact selection of water transfer mechanisms.

Second, the organizational skills and leadership ability held by state agencies versus individual water users is a factor in reallocation approaches. Where individuals lack organizational ability, markets may be unable to function and a government agency may be able to supply the integration required for orderly transfers of water. However, if agencies themselves are lacking organizationally, market failure may be replaced with government failure.

Similarly, a third set of considerations is the analytical skill and independence of an agency potentially involved in crchestrating water transfers. The agency must have the ability to accurately evaluate the economic tradeoffs (gains and losses) involved in a potential transfer. Moreover, the agency must not be biased towards or against a particular user group. At the same time client relationships with agriculture, industry and municipalities must be maintained in order to have broad based political support.

Finally, a fourth consideration is the scale of the transfer involved. In order for large scale transfers to be efficient, as in water resource management in general, a system wide evaluation must be undertaken (Easter, Dixon and Hufschmidt, 1986). As a rule, governments, rather than individuals, are in a position to do so.If water transactions are taking place on a small scale within use type, it is more likely that individuals working through markets cau function effectively. However, the larger the scale of the proposed water reallocation, the more likely it is that state agencies must be involved to evaluate, negotiate, and implement the transfer. For example, in interbasin transfers or large scale transfers between use types, administrative mechanisms may play a larger role.

The foregoing principles not withstanding, it is useful to characterizc alternative approaches to water transfers, and typical advantages and disadvantages of each. The following paragraphs discuss a variety of institutional arrangements that have been employed to deal with changes in water supply and demand, and resulting water transfers. Fluctuating conditions that provide the impetus for water reallocation can be either shortrun and longrun. supply-side changes ten to be relatively shortrun (e.g. drought) but conceivably could be long run (as in the case of climatic change). Demand-side changes are usually relatively longrun, or permanent. As a result, transfers elicited on these grounds tend to be substantially more controversial. 


\section{Supply side Impetus for Transfers : Drought}

Times of unusually short water supply or prolonged drought call for special institutional arrangements for water allocation. Coping with drought often calls for reallocation of water both within and between sectors. In order to minimize overall economic disruption, the most profitable and drought sensitive enterprises must be assured continued water supply, while less sensitive and less economically important endeavors must be sacrificed. For example, within agriculture, tree orchards should have priority over hay production on economic grounds. Between sectors, providing municipal water at the expense of agriculture is usually economically justified. Institutional arrangements determine the degree of difficulty encountered in achieving needed water reallocation.

\section{Market Based Priority}

Adaptation to drought in colorado is achieved through market reallocation based on the institution of priority coupled with tradeability (regarding ownership) and transferability (regarding location). As explained previously, water rights are defined such that senior (older) rights are fulfilled prior to junior (more recent) rights. Therefore, rights are diffr:entiated with respect to the probability of receiving water under given precipitation conditions. Priority becomes even more important in times of water shortage. of course, there is no guarantee the within the initial allocation of water, the most senior right carries the greatest net economic benetit. Economically efficient reallocation is made possible only because water rights are tradeable, and therefore flexible.

Drought sensitive enterprises may take one of two approaches in order to be assured of water supply during drought years. First, a sufficiently senior water right may be purchased from an existing water user. The mora senior a water right is, the more valuable it is it terns of certainty of supply. only those enterprises with large profit margins, or with great ability to pay (e.g. municipalities) will be in a position to buy senior water rights. Second, it may be possible to buy a "drought year option" (Michelsen and Young, 1990). In this case a contract is drawn up wherein a right holder with a low valued use agrees, for a monetary consideration, to forego water use and transfer it to a high valued - use, under conditions of drought. This alternative dues not require permanent water transfers and is, in all likelihood, less disruptive to local economies when water shortages are fairly rare. 
It is fairly typical for water allocation during drought conditions to be decided through bureaucratic means, via private water user groups or by the state itself.Various techniques are used by bureaucracies to reallocated water, each with specific efficiency and equity implications.

Drought year water allocation in valencia, spain is representative of many privately organized water distribution systems. Private institutional arrangements specify that in times of shortage, water is to be allocated proportionate to land holdings among irrigators (Maass and Anderson, 1978). The result is greater time intervals between water deliveries. No prioritization among farmers is made, indicating that the primary goal is equity, rather than economic efficiency. In some areas, such as Pakistan, proportionate allocation is found to be ineffective or unworkable, due to conveyance losses. In response to this physical problem, water allocation is prioritized based on location, i.e., proximity to head waters (Chaudhry and Young, 1990).

In response to the 1990-91 drought in Thailand, the Royal Irrigation Department engaged in a kind of rationing. officially, water for electricity generation carries first priority. This is based on its higher economic return (Boonkrob, Thongdeelert, Ayuthdhaya and Sripim, 1991). Consequently, reductions in acreage for some crops were ordered. Other plantings were delayed while some were increased. Implicitly, this rationing may have mimicked what markets would accomplished, but without compensation and transactions costs.

Recent events in California demonstrate the force that natural circumstances can have on the pressure for more flexible institutional arrangements. California is a state that has historically relied reductions in overall use rather than reallocation between sectors as a means to deal with water shortage. However, in February of 1992, after five years of drought, the California legislature and California Department of Water Resources (CDWR) abandoned rationing, in favor of a form of trading. A "drought emergency water bank" was established (Macaulay, 1991).

The state wide water bank allowed market like transfers. However, a significant amount of bureaucratic control is involved. First, all trades are administered by CDWR using uniform contracts. Based on expert economic advise, the price of water was fixed at CDWR's buying price of $\$ 125$ per acre foot and a selling price of $\$ 175$ per acre foot. The difference was estimated to cover transportation, negotiation and administrative costs. 
The water bank program was highly successful in transferring water from less to me =e economically sensitive sectors of the state. Over 600,000 acre feet of deliverable water supplies were purchased, with approxinately 400,000 acre feet sold and 200,000 kept as carry over and for fish and wildlife uses. As expected, the big sellers were farmers in Northern California. Water purchases were made by farmers with permanent crops and urban users in Southern California, with over half going to the Metropolitan Water District of Southern California (Macaulay, 1991).

\section{Demand side Impetus for water Transfers}

Transfers of water are often stimulated by changes in the economic demand for water. The most typical case is in of general municipal and industrial growth. The result is p) are to move water between sectors (out of agriculture into high is alised uses) or between regions (from one locality to another). '...ever. changes in demand for water also occur within sectors. Sh, s.991) suggests water markets are critical to farmers in India who iav not share in an initial allocation of water, yet wish acquir, the resource in pursuit of economic opportunity.

Because such transfers tend to be permanent, rather than temporary as in the case of drought, they are usually more controversial. Institutional arrangements for dealing with this type of transfer range from the absence of any rule, to complete bans on transfers, to (perhaps undue) institutional accommodation of permanent transfers. The following paragraphs contrast alternative approaches to demand side transfers, including the advantages and problems associated with each type.

Institutional Voids for Transfer

The current situation in Thailand exemplifies a case where no steadfast rules exist for either intersectoral or interregional transfers. The result is near chaos, and a growing demand for innovation ir. water institutions to deal with the insecurity and inefficiencies that result (Johnson, et. al., 1990). This applies to transferability as well as general water allocation.

During the past decade, Thailand has experienced exponential industrial economic growth, accompanied by a concomitant increase in overall water demand. Industrial users have met this demand by constructing new diversion works, or by pumping water from existing irrigation canals (Johnson, et. al., 1990). This is done without regard to its very substantial impact on the water quality or quantity available to downstream users. In effect, de facto transfers have occurred, as enabled by the institutional void. water reallocation depends solely on technology, backed by political power. 
Transfers of water from agxiculture to industrial uses in Thailand may be justified on economic grounds. However, no institutional provision is made for formal purchase from existing users. No compensation for reallocation occurs; water is taken, not traded. These transactions may meet the criterion of standard benefit cost analysis, wherein those who gain could (but may not) compensate losers and still be better off. However, a fundamental equity requirement of voluntary market transactions (actual compensation as required by Pareto optimality) has been violated, making such transfers ethically offensive and economically disruptive. The institutional void creates uncertainty and dampens investment.

\section{Bans on Permanent Water Transfers}

In many societies, principles of fairness override efficiency concerns when it comes to permanent water transfers. For example, the Great Lakes states in the U.S. officially denounce transfers of Great Lakes water out of the region, regardless of the reason. Any proposed transfer out of the region requires consensus approval by all Great Lake states. Therefore, any state has veto power. Given most transfers do impose some costs, proposals for moving water out of the basin are almost guaranteed to fail. (It must be noted that Federal interstate commerce law may override this arrangement among States.)

Bans on permanent water transfers are often acccmplished by adopting institutional arrangements that make water appurtenant to land. This principle pervades many areas of the developed and developing world (Maass and Anderson, 1978). In the U.S., Elwood Mead was very influential in advancing the notion that water should be appurtenant and not change in location. This system is embedded in Wyoming water law as well as elsewhere in the states.

The water allocation system in Valencia, spain, is typical of many around the world. Water rights are appurtenant to specific tracts of land. In spain, individual users belong to an irrigation group. Water is allocated proportionately among landholders according to the size of their holdings. Quoting from (Maass and Anderson, 1987, p. 41) .."the sale of water or of the rights to water is anathema to valenciars, where water is married to land and cannot be divorced from it." spanish institutional arrangements establish certainty and a form of equity at the expense of efficiency in water allocation. 


\section{Market systems for Transfer}

In parts of the western U.S., notably colorado, market transfers of water are possible within the overall institutional framework. However, transfers are subject to the absence of damage rule. Any party (senior or junior) who claims to be injured, either in terms of quantity or quality of water availability, may bring suit to stop the proposed transfer, insuring external impacts on other water users are considered.

The effect of the absence of damage rule purtaining to transfers has traditionaliy translated into the notion that only "consumptive" water use can be permanently transferred, rather than the full amount withdrawn from the stream. Return flows must remain intact in order to prevent injury to downstream water users.

The informal "consumptive" use transfer rule has been complicated by the introduction of instream water rights. Environmencal uses of water are increasingly recognized, which usually involve a specific amount of water remaining in the stream at a given locality, for wildlife or recreational use. If instream water rights are located near the site of a transfer, even limiting the transfer to consumptive use only may impact the quantity of water available for an instream right. In this case, the absence of damage rule may disallow any transfer of water (Livingston and Miller, 1986). The problem is particularly acute on over appropriated streams with variable flow. A California Department of Water Resources report also documents this issue as a problem arising out of water bank operations (Macaulay, 1991).

Market based water transfers are not without problems (Saliba, 1987). There are several factors that hamper permanent intersectoral water reallocations. These include hydrologic and technical limitations, transactions costs, and secondary impacts. At least in the case of the first two, institutions and technology can be used to minimize their impact. The last consideration is more complicated and is a significant concern in water transfers under the most developed institutional arrangements. The following paragraphs describe each consideration in turn.

Impacts of Infrastructure on Transfers and the Value of Water

Physical circumstances, as well as the economic value of water in alternative uses, determine the gains from trade so critical to market transfers. Transportation costs alone may stymie a potential market (Livingston, 1985). Consider market transfers from agricultural to municipal use. Clearly, based on the economic value in use, municipal users would be willing and able to bid water away from agricultural users. However, if agricultural water is not readily accessible to the municipality's natural or man-made conveyance system, the cost of transportation facilities necessary to complete the transfer may render the transaction uneconomical. 
Typically, a transfer must be fairly substantial in order to justify the cost of physically connecting water systems. Whenever possible, it makes economic sense to litilize the existing water courses to implement water transfers. Barring extrene circumstances, it is useful for the analyst to think in terms of a set of relatively independent market regions defined by water basin, rather than envisioning an entire region or nation as a viable water market.

In this context, it is clear why the Colorado Big Thompson project in colorado is usually cited as an ideal, and certainly one of the very few,large scale water market in operation today. Large, centralized stored water supplies are most amenable to water marketing because transportation and return flow issues are minimized. CBT project facilities connect three major watersheds with a highly centralized stored water supply.

In the same vein, expanding water markets nay require additional physical linkages. The Northern Colorado water Conservancy District, (the agency that operates CBT water) has conducted a long term study of ways to accommodate uneven growth in regional water demand. The result is a proposal to develop additional infrastructure and to expand integrated (centralized) water treatment (NCWCD,1991). Shah (1991) also sees infrastructure as key to the development of water markets in India.

Based on the discussion above, it is clear that many state and federal agencies have the opportunity to provide leadership in water marketing. Large scale water supplies are typically controlled by these agencies. Unfortunately, many of these same agencies employ policies that explicitly prohibit gains from trade via water transfers. Policy makers should consider institutional innovations that allow efficient transfers.

Transactions costs

The term "transaction cost" refers to the monetary expense of completing a particular transaction. In this case the transaction is the transfer of a water right. Typical transaction cosis incurred in such a transfer include the cost of negotiation witi. the other water user(s) involved and the costs of fulfilling legal and/or administrative costs associated with completing the transfer.

Rather than being a minor consideration in water transfers, transaction costs have proven to be a major element. They are often substantial enough to delay or prevent water transfers altogether. Transaction costs have been cited as the reason why more water transfers do not take place, even when large differences in the value of water in alternative uses exist (Young, 1986; Ingram and oggins, 1990). Ingram and oggins(1990) note that a transfer of 15,000 acre feet of water in Nevada required 15 months of 
transaction time and that in Utah, 7 of the 85 million dollars spent of water rights for the Intermountain Power Project went to lawyers and engineers.

A pending water transfer in colorado also exemplifies the complexities in transaction, even under the most market like conditions. Beginning in 1985, in an effort to procure municipal water supplies, the Denver suburb of Thornton purchased approximately 20,000 irrigated acres and the water shares associated with them. In this case agricultural water is provided by Water supply and storage company in rural northern colorado. simultaneously, Thornton applied for roughly 18,000 a.f. of unappropriated water on the Poudre River.

Certainly, the amount Thornton is willing to pay for water far exceeds the value of water in agriculture. On these grounds, there should be substantia. gains from trade. Despite the basic economic incentive involved, the actual transaction has been very complicated. After six years, the transfer remains in limbo in the court system. There are a variety of agencies involved, each of which have spent untold amounts of money to defend their position.

While the irrigation company itself initially balked at the transfer, with great concern about Thornton monopolizing its supply, they were soon able to reach agreement. However, both Cache La Poudre water User Association and Northern Colorado Conservancy District are claiming injury. The former agency is concerned mainly about the quantity of water available to its members if the transfer occurs. They claim Thornton's transfer will affect the timing and amount of return flows in the Poudre River, and will stymie many long term exchange arrangements on the river.

NCWCD is also concerned with the changes in water quality arising from the proposed transfer, especially considering quickly evolving water quality regulations. NCWCD also contests water applications that are based on dubious population growth projections. An over arching issue also pertains to the amount of WSSC water that is subject to the regular "consumptive use" rule and the amount that is exempt, due to special "importation" considerations.

As explained previously, the only constraint to water acquisition or transfer in Colorado is the "absence of damage" rule. That is, any party who claims injury due to the transfer may appeal to the courts. Establishing injury takes legal time and money, which amounts to transaction cost. Many transfers of the type Thornton is proposing are expected in the future. The final decision on the proposed Thornton transfer will be precedent setting. One thing is very clear. Market based water transfers will have to overcome very substantial transaction costs in order to become a reality. 


\section{Secondary Impacts of Water Transfers}

As discussed in the context of market failure, efficient resource use requires that externalities be accounted for in decisions to transfer water. Simply stated, this means that any change in water allocation cannot have uncompensated effects on other water users. However, this stipulation does not take into consideration that there may be other parties, who are not water users, who are adversely impacted. These "secondary impacts" tend to be on people who supply water users and the community at large (Howe and Easter, 1971).

Including impacts on suppliers and community tax base is relatively simple. Theoretically, these impacts are negligible if full employment exists and resources are completely mobile. Under these conditions, losses in the water selling area are offset by gains in the purchasing area. However, some unemployment, and imperfect resource mobility is the rule, rather than the exception. Moreover case, the distribution of economic activity is of concern to local officials, regardless of aggregate impacts (Nunn, 1985; Fort Collins Coloradoan, 1987). Input-output analys is can be used to estimate secondary impacts (Young, 1984). A study of the California water bank shows significant and differential secondary impacts by crop type and by region (Macaulay, 1991).

Beyond economically identifiable third party impacts, water transfers are often objected to on more general ethical grounds (Brown, McDonald, Tysseling and DuMars, 1982). Around the world, transfers are often resisted because they may engender "speculation", "capitalist accumulation"(Maass, 1990) and "water hogging". There is also evidence that community members perceive a loss in opportunity for growth, a loss of culture and control over the future (Ingram, 1990) and an unfounded emphasis on individual over community values (Nunn,1990) when water is transferred permanently out of a locality.

\section{Administrative systems for Transfer}

Certainly, market systems for water transfers are the exception, rather than the rule, throughout the world. Many countries, because of inexperience with market systems, recognition of the problems outlined above or simply because of historical, cu'tural and political circumstances, have adopted administrative systems that reallocate water. The following paragraphs describe some alternative administrative approaches that have been taken, along with some discussion about their strengths and weaknesses. 
In general, many countries throughout Asia currently lack the experience or institutional foundation necessary to undergird market transfers of water (Berkoff). Unfortunately, many of the administrative systems in place also lack the basin-wide focus, organizational skills, independence and technical information required to implement efficient water reallocation.

The Philippines exemplifies countries that face serious problems in water administration (Cruz, Cornista and Dayan, 1987). specifically, this study reports that staff charged with implementation of the current water code lacks the technical ability to estimate true water availability and to evaluate the impact of water allocations on third parties (exiernalities). Moreover, there is a systematic bias in water allocation in favor of landowners and against irrigators. Finally, due to organizational problems, the process is rife with delays.

However, there are examples of relatively efficient administrative systems in Asia. Management of the Mahawela in Srilanka and the Bhakhra Beas Management Board in India come fairly close to meeting the criteria for efficient water allocation (Berkoff, 1991). Both employ a basin-wide focus and use relatively sophisticated evaluation techniques. Real time management is based on a yearly seasonal plan, and subsequently on monthly policy and weekly technical meetings.

In Australia, institutions for water transfer are evolving rapidly. There are increasing pressures to develop water institutions that are flexible, because economic development has been impeded by fixed allocations of water. Currently, the institutional system is somewhere between a complete ban on transfers and voluntary market transfers. Until recently, water rights were attached to land and not officially transferable. In practice, transfers were achieved primarily through changing the conditions attached to permits, at the time they are renewed.

The state retains the power to change the conditions attached to permits, thereby reallocating water, based on the perceived relative importance of various sectors and enterprises within sectors. Conceivably, the intent may be to mimic what markets would accomplish. However, given the information intensive nature of such a task, and the great advantages of a price system in this regard, it is doubtful a centralized agency would accomplish this reallocation efficiently.

Since the middle 1980's, however, in response to the problems inflexibility generated, institutional arrangements are changing to accommodate transfers. However, they must be pursued through and sanctified by the state bureaucracy. Additional conditions may be attached to the transfer on a case by case basis (Maass, 1990). It is significant that the price attached to the transfer is negotiated without state interference. 
Some private water agencies in the U.S. allow transfers, subject to agency conditions including price restrictions. For example, Kern County Water Agency stipulates that any water sold through the "pool" cannot carry a price in excess of the original cost of the water (Livingston, 1982). Essentially, the policy states that no profit may be achieved via transfers. This policy presumably discourages speculation, a recurrent theme in public policy debate about water transfers. Unfortunatel", in the process of negating profit, the vital mechanism that spurs efficiency through competition is rendered inoperable.

In the United States, New Mexico employs an administrative system for water reallocations, that appears to be quite efficient. Any individual may apply for a water transfer. The application will be approved "if the state engineer determines that the change is not detrimental to existing water rights, is not contrary to the conservation of water within the state, and is not detrimental to the public welfare of the state (Ninn and BenDavid, (1991). Therefore, great responsibility for determining economic merit rests on the state engineer.

Evidence suggests that in fact, most transfer decisions have been based on an evaluation of aggregate benefits and cost, which mimics the incentives that drive markets. Historically, decisions have been independent, in that the users to whom benefits and costs accrued has not been a concern, per se. However, increasingly, secondary impacts have become a consideration. Given an effective organization and a system wide scope, this system has some great advantages in terms of reducing transactions costs.

\section{SUMMARY}

The foregoing discussion rests on the well known premise that in order to foster economic efficiency, rights to water resources musc be both secure and flexible. Designing institutions to deal with the physical peculiarities of water in a way that establishes sensible incentives and enables efficient resource use is complicated, at the very least.

Fundamentally, establishing security in water rights requires that water users are protected against intrusion by others. This is challenging given that water users are naturally interdependent. Security does not mean that one must be juaranteed an exact amount of water, all the time. Rather, security means knowing the probability of water availability, and being certain about allocation procedures under changing circumstances. 
Security means that established water users are protected against new users and against erratic acts by policy makers. Australian's face uncertainty dise to a substantial number of sleeper rights. Americans face uncertainty due to newly activated reserved rights and changes in environmental policy. Perhaps perfect security is unattainable in an ever changing world.

Economic efficiency in water allocation, in response to short term supply changes, such as drought, requires that economically sensitive sectors take precedence over less sensitive or more adaptive sectors. This can be accomplished through markets or by administrative means(i.e. by government agencies or private water user groups). In a market scheme, rights must be differentiated according to the probability of receiving water in times of shortage. High valued uses can then either acquire high probability rights permanently, or can negotiate an option to be exercised only in drought years.

There is less agreement among experts about designing institutions to provide flexibility in water allocation in response to long run changes in water demand. Certainly, no one interested in economic efficiency would suggest either a complete ban on transfers or completely unrestrained transfers. The basic difficulty is in insuring that water transactions allow economic development and do not impose externalities on other water users.

Market mechanisms for water transfer can entail substantial transaction costs, which threaten to delay or stymie transfers altogether. Moreover, third party and community impacts continue to be of concern to those involved in water transfers. Local citizens and officials raise issues concerning the distribution of economic activity, rather than its aggregate level (economic efficiency). Perhaps these issues are negligible when the amount of water transferred is small in proportion to total supply. However, when the transfer threatens the fundamental economic base of a community, these concerns deserve more consideration.

Successful water institutions require a delicate interplay between administrative and market control. Institutions establish the basis for market and can assure competitive conditions. Water agencies will always be involved in allocation, given the economies of scale in centralized water management. Structuring institutions such that the overall incentive that emerge foster sound economic development poses a critical challenge for water resource professionals. 


\section{REFERENCES}

Anderson, T. I. Water Rights: Scarce Resource Allocation, Bureaucracy and the Environment, San Francisco: Pacific Institute for Public Policy Research, 1983.

Berkoff, J. "South Asia and East Asia and Pacific Regions: Asia Water Resources Study" draft World Bank Report, 1991.

Boonkrob, P., C Thongdeelert, P.N.N. Ayuchdhaya an O. Sripim. "Local Water Resource Management, Thailand", 1991

Bromley, D. W "Land and water Problems: An Institutional Perspective," American Journal of Agricultural Economics, 64:834844,1982 .

Brown, L., B. McDonald, J. Tysseling and C. DuMars. "Water Reallocation, Market Proficiency and Conflicting social Values," in Water and Aariculture in the Western U.S., G. D. Weatherford, ed., Boulder: Westview Press, 1982.

Burness, H. S. and J. P. Quirk, "Water Law, Water Transfers, and Economic Efficiency: The Colorado River, The Journal of Law and Economics, : 111-134, .

Cestti, R., "Water Resources: Problems and Issues for the water Supply and Sanitation Sector", World Bank working paper, INUWS, August, 1989.

Chaudhry, M.A. and R.A. Young. "Economic Impacts of Alternative Irrigation Water Allocation Institutions: Pakistan's Warabandi System" in Social. Economic and Institutional Issues in Third World Irrigation Management, R.K. Sampath and R.A. Young, eds., Boulder:West:view Press, 1990.

Ciriacy-Wantrup, S. V. "Concepts Used as Economic Criter:' for a System of Water Rights" Land Economics 4:295-312, 1956.

Cruz, C. J., I. B. Cornista and D. C. Dayan. "Legal and Institutional Issues of Irrigation water Rights in the Philippines", Agrarian Reform Institute, University of the Philippines at Las Banos, 1987.

Delforce, R. J., J.J. Pigram, W. Musgrave and R. L. Anderson. "Impediments to Free Market water Transfers in Australia" in Transferability of Water Entitlements, Center for water Policy Research, Armidale, Australia, 1990. 
Dudley, N. J. "Water Allocation by Markets, Common Property and Capacity Sharing: Companions or Competitors", Centre for Water Policy Research, University of New England, New South Wales, 1991.

Dunbar, R. G. "The Adaptation of Groundwater control Institutions to the Arid West." Agricultural History, 51:662-680, 1977.

Easter, K. W., J. A. Dixon and M. M. Hufschmidt, eds., Watershed Resources Management, Boulder, CO: Westview Press, 1986.

Fallon, L. A. and J.A. Dixon, "Scarcity without Shortage: Water Demand Management in the Beijing-Tianjin Region of China", proseedings of the International Water Resources Association meeting, ottawa, 1989.

Fort Collins Coloradoan. "Increased Demand Creates Controversy: Northern Colorado Fights Back." December 27, 1987.

Gisser, M. and R. N. Johnson, "Institutional Restrictions on the Transfer 0 : Water Rights and the Survival of an Agency", in Water Rights, T.i. Anderson, ed., San Francisco: Pacific Institute for Public Poili v Research, 1983.

Hartman, $\because$ M. , and D. Seastone. Water Transfers: Economic Efficiency and Alternative Institutions, Baltimore: John Hopkins Press, 1970 .

Howe, C. W. and K. W. Easier, Interbasin Transfer of Water:Economic Issues and Impacts Baltimore: John Hopkins Press, 1971.

Howe, C. W., D. R. Schurmeier and W. Douglas, "Innovative Approaches to water Allocation: The Potential for Water Markets." Water Resources Research, 22:439-445, 1986.

Ingram, $H$. and C. R. Oggins. "Water, The community and Markets in the West", Udall center for studies in Public Policy Working Paper, University of Arizona, July, 1990

Johnson, S. H. , P Patamatamkul, T. Onchan and U. Tan-Kim-Yong. "River Basin Water Manacjement Proposal Preliminary study Design (Thailand)" ISPAN Report No. 36, 1990.

Kelso, M. M., W. E. Martin and L. E. Mack. Water Supplies and Economic Growth, Tucson: University of Arizona Press, 1973.

Livingston, M.L. "Optimal water Institutions for Arid Environments", in Arid Lands:Today and romorrow, Whitehead, E., C. Hutchinson, B. Timmerman and R. Varady, eds., Boulder:Westview Press, 1988. 
Livingston, M.L. "Evaluating the Performance of Environmental Policy:Contributions of Neoclassical, Public Choice and Institutionalist Models", Journal of Economic Issues, 21:281294,1987 .

Livingston, M. L. "Water Allocation Agencies: Transfer Policy and Economic Efficiency", NRE Staff Report AGES820609,U.S.D.A., 1982.

Livingston, M.L. and T. A. Miller. "A Framework for Analyzing the Impact of Western Instream Water Rights on Choice Domains: Transferability, Externalities and Consumptive Use", Land Economics, $62: 269-277,1986$.

Livingston, M. L. and V. W. Ruttan. "Efficiency and Equity in Institutional Development: A Perspective on Water Resources in the Arid West", Rivers: studies in the Science, Environmental Policy and Law of Instream Flow 1:218-226,1990.

Maass, A. "Water Law and Institutions in the Western U. S.: Comparisons with Early Developments in California and Australia, Contemporary Developments in Australia and Recent Legislation Worldwide" Presentation at the Natural Resources Law Center, University of Colorado, september, 1990.

Maass, A. and R. I. Anderson. "... And The Desert shall Rejoice:Conflict, Growth and Justice in Arid Environments, Cambridge: The MIT Press, 1878.

Macaulay, s. "Water Marketing in California as a strategy to Meet Future Urban and Irrigation Demands", presentation to the U.S. committee on Irrigation and Drainage 12 th Technical Conference on Irrigation, Drainage and Flood Control, San Francisco, November 1316, 1991.

Michelsen, A. M. and R. A. Young. "Drought-Year options on Agricultural Water Rights for Urban water supplies" in Transferability of Water Entitlements. The center for water Policy Research, Armidale, Australia, 1990.

Northern Colorado Water Conservancy District, "District Releases Regional water supply study, Water News, Fall, 1991.

North, D. C. "Institutions, Transactions Cost and Economic Growth", Economic Inquiry, 25:419-428, 1987.

Nunn, S. C. "Alternative Water Transfer Forums: Social and Community Impacts" in Transferability of water Entitlements, The Center for Water Policy Research, Armidale, Australia, 1990.

Nunn, S. C. "The Political Economy of Institutional Change: A Distributional Criterion for Acceptance of Groundwater Rules", Natural Resources Journal 25:867-892,1985. 
Nunn, S. C. and S. BenDavid. "Expediting Change in Water Use" Hydrologic Criteria and Market Transactions". Technical Completion Report Project Numbers 14-08-001-G1646, 1423623, 1345685, New Mexico Water Resources Research Institute, 1991.

Randal1, A. "The Problem of Market Failure" Natural Resources Journal, 23:131-148,1983.

Runge, C. F. "Induced Agrisultural Innovation and Environmental Quality: The Case of Groundwater Regulation." Land Economics, $63: 249-258$, 1987 .

Ruttan, V. W. and $Y$. Hayami. "Toward a Theory of Induced Institutional Innovation." Journal of Development studies, $20: 203-223,1984$.

Saliba, B. C. "Do Water Markets 'Work'? Market Transfer and Trade-offs in the Southwestern states." Water Resources Research, 23:1113-1122, 1987 .

Schmid, A. A. "Analytical Institutional Economics: Changing Problems in the Economics of Resources for a New Environment." American Journal of Agricultural Economics, 54:893-901, 1972 .

Shah, T. "Water Markets and Irrigation Development in India." Indian Journal of Agricultural Economics, 46:335-348, 1991.

Vaux, H. J. "Economic Factors Shaping Western Water Allocation." American Journal of Agricultural Economics, 68:1135-1142, 1986.

Young, R. "Why Are There so Few Transactions Between Water Users?" American Journal of Agricultural Economics, 68:1143-1151, 1986.

Young, R. "Direct and Regional Economic Impacts of Competition for Irrigation Water", in Water Scarcity: Impacts on Western Agriculture, Englebert and Scheuring, eds.,Berkeley: University of California Press, 1984.

Young, R., J. T. Daubert and H. J, Morel-Seytoux. "Evaluating Institutional Alternatives for Managing an Interrelated streamAquifer system. American Journal of Agricultural Economics $68: 787-$ $797,1986$. 


\section{Pollcy Research Working Paper Series}

\begin{tabular}{|c|c|c|c|c|}
\hline & Title & Author & Date & $\begin{array}{l}\text { Contact } \\
\text { for paper }\end{array}$ \\
\hline WPS1208 & $\begin{array}{l}\text { Primary School Achievement in } \\
\text { English and Mathematics in } \\
\text { Zimbabwe: A Multi-Level Arialysis }\end{array}$ & $\begin{array}{l}\text { Levi M. Nyagura } \\
\text { Abby Riddell }\end{array}$ & October 1993 & $\begin{array}{l}\text { 1. Conachy } \\
33669\end{array}$ \\
\hline WPS1209 & $\begin{array}{l}\text { Should East Asia Go Regional? } \\
\text { No, No, and Maybe }\end{array}$ & Arvind Panagariya & October 1993 & $\begin{array}{l}\text { D. Ballantyne } \\
37947\end{array}$ \\
\hline WPS1210 & $\begin{array}{l}\text { The Taxation of Natural Resources: } \\
\text { Principles and Policy Issues }\end{array}$ & $\begin{array}{l}\text { Robin Boadway } \\
\text { Frank Flatters }\end{array}$ & October 1993 & $\begin{array}{l}\text { C. Jones } \\
37699\end{array}$ \\
\hline WPS1211 & $\begin{array}{l}\text { Savings-Invesiment Correlations } \\
\text { and Capital Mobility in Developing Cou }\end{array}$ & $\begin{array}{l}\text { Nlandu Mamingi } \\
\text { untries }\end{array}$ & October 1993 & $\begin{array}{l}\text { R. Vo } \\
31047\end{array}$ \\
\hline WPS 1212 & $\begin{array}{l}\text { The Links between Economic Policy } \\
\text { and Research: Three Examples from } \\
\text { Ghana and Some General Thoughts }\end{array}$ & Ravi Kanbur & October 1993 & $\begin{array}{l}\text { P. Attipoe } \\
526.3003\end{array}$ \\
\hline WFS1213 & $\begin{array}{l}\text { Japanese Foreign Direct Investment: } \\
\text { Recent Trends, Determinants, and } \\
\text { Prospects }\end{array}$ & $\begin{array}{l}\text { Kwang W. Jun } \\
\text { Frank Sader } \\
\text { Haruo Ho: aguchi } \\
\text { Hyuntai Kwak }\end{array}$ & November 1993 & $\begin{array}{l}\text { S. King-Watson } \\
33730\end{array}$ \\
\hline WPS1214 & $\begin{array}{l}\text { Trade, Aid, and Investment in Sub. } \\
\text { Saharan Atrica }\end{array}$ & Ishrat Husain & November 1993 & $\begin{array}{l}\text { M. Youssef } \\
34637\end{array}$ \\
\hline WPS1215 & $\begin{array}{l}\text { How Much Do Distortions Attect } \\
\text { Growth? }\end{array}$ & William Easterly & November 1993 & $\begin{array}{l}\text { R. Martin } \\
39055\end{array}$ \\
\hline WPS1216 & $\begin{array}{l}\text { Regulation, Institutions, and } \\
\text { Commitment: Privatization and } \\
\text { Regulation in the Argontine } \\
\text { Telecommunications Sector }\end{array}$ & $\begin{array}{l}\text { Alice Hill } \\
\text { Manuel Angel Abcala }\end{array}$ & November 1993 & $\begin{array}{l}\text { D. Evans } \\
38526\end{array}$ \\
\hline WPS1217 & $\begin{array}{l}\text { Unitary versus Collective Models } \\
\text { of the Household: Time to Shift the } \\
\text { Burden of Proof? }\end{array}$ & $\begin{array}{l}\text { Pierre-Andre Chiappori } \\
\text { Lawrence Haddad } \\
\text { John Hoddinott } \\
\text { Ravi Kanbur }\end{array}$ & November 1993 & $\begin{array}{l}\text { P. Attipoe } \\
526-3002\end{array}$ \\
\hline WPS1218 & $\begin{array}{l}\text { Implementation of Trade Reform in } \\
\text { Sub-Saharan Atrica: How Much Heat } \\
\text { and How Much Light? }\end{array}$ & John Nash & November 1993 & $\begin{array}{l}\text { D. Ballantyne } \\
37947\end{array}$ \\
\hline WPS1219 & $\begin{array}{l}\text { Decentralizing Water Resource } \\
\text { Management: Economic Incentives, } \\
\text { Accountability, and Assurance }\end{array}$ & $\begin{array}{l}\text { K. Willam Easter } \\
\text { Robert R. Hearne }\end{array}$ & November 1993 & $\begin{array}{l}\text { M. Wu } \\
30480\end{array}$ \\
\hline WPS 1220 & $\begin{array}{l}\text { Developing Countries and the } \\
\text { Uruguay Round: Negotiations on }\end{array}$ & Bemard Hoekmian & November 1993 & $\begin{array}{l}\text { L. O'Connor } \\
37009\end{array}$ \\
\hline
\end{tabular}

Services 


\section{Policy Research Working Paper Serles}

Title

WPS1221 Does Research and Development
Contribute to Economic Growth
in veveluping Countries?

WPS1224 Devaluation in Low-Inflation Economies

WPS1225 Intra-Sub-Saharan Atrican Trade: Is It Too Little?

WPS1226 Forecasting Volatility in Commodity Markets

WPS1227 Designing Water Institutions: Market Failures and Institutional Response

WPS1228 Competition, Competition Policy, and the GATT
Author

Nancy Birdsa!l

Changyong Rhee

Faezeh Foroutan

Martin Ravallion

Benu Bidani

Miguel A. Kiguel

Nita Ghei

Faezeh Foroutan

Lant Pritchet:

Kenneth F. Kroner

Devin P. Krieafsey

Stijn Claessens

Marie Leigh Livingston

Bernard M. L ioekman

Petros C. Mavroldis

\section{Date}

Contact for paper

November 1993

S. Rajan 33747

November 1993

S. Fallon 38009

November 1993

P. Cook 33902

November 1993 R, Luz 39059

November 1993

S. Fallon 38009

November 1993

F. Hatab 35835

December 1993

C. Spooner 30464

December 1993

L. O'Connor 37009 